\title{
JUDICIAL COOPERATION IN CIVIL AND COMMERCIAL MATTERS AFTER BREXIT: WHICH WAY FORWARD?
}

\author{
Giesela RÜHL*
}

\begin{abstract}
Judicial cooperation in civil and commercial matters is generally perceived to be of a rather 'specialist and technical nature'. However, for the many UK and EU citizens, families and businesses who work, live, travel and do business abroad, the current European framework for choice of law, jurisdiction and recognition and enforcement is of paramount importance. The article, therefore, explores how that framework might look like after Brexit and explores the merits and demerits of the various ways forward. It argues that the best option for both the UK and the EU would be to agree on the continued application of the existing EU instruments or to strive for conclusion of a new agreement that closely replicates these instruments. If no such agreement can be reached the UK should decide to apply the Rome I and Rome II Regulations unilaterally and sign the Lugano Convention of 2007 as well as the Hague Convention on Choice of Court Agreements of 2005.
\end{abstract}

Keywords: Brexit, Brussels Ia Regulation, Brussels Convention, choice of law, Court of Justice of the European Union, Hague Choice of Court Convention, jurisdiction, Lugano Convention, recognition and enforcement, Rome I Regulation, Rome II Regulation, Rome Convention..

\section{INTRODUCTION}

On 29 March 2017 Theresa May, Prime Minister of the United Kingdom, notified Donald Tusk, President of the European Council that the United Kingdom wished to withdraw from the European Union. After a process that started with the Brexit Referendum on 23 June 2016, and following a decision of the Supreme Court ${ }^{1}$ as well as approval of the Lower and the Upper Houses of the UK Parliament ${ }^{2}$ (and the Royal Assent) there is now little doubt ${ }^{3}$ that the European Union, for the first time in its history, will lose

\footnotetext{
* Professor, Faculty of Law, Friedrich-Schiller-University Jena, giesela.ruehl@uni-jena.de.

1 Supreme Court of the United Kingdom, Miller v Secretary of State for Exiting the European Union, [2017] UKSC 5. $\quad 2$ European Union (Notification and Withdrawal) Act 2017, c. 9.

3 Note that a number of authors have recently suggested that the withdrawal notification may be revoked unilaterally by the UK. See, for example, the so-called 'Three Knights Opinion' by D Edward, F Jakobs, J Lever et al., 'In the Matter of Article 50 of the Treaty on European Union', para 2 (vi), 36ff <https://www.bindmans.com/uploads/files/documents/Final_Article_50_ Opinion_10.2.17.pdf >; P Craig, 'Brexit: Foundational Constitutional and Interpretive Principles:
} 
a Member State. ${ }^{4}$ What this will mean for the UK and the European integration project in the long run is, of course, an open question. In the short run, however, Brexit creates the need to put the relationship between the EU and the UK on a new footing.

Unfortunately, however, it is still largely unclear what this relationship will look like: the Brexit negotiations between the EU and the UK that started in June 2017 have not yet yielded any tangible success as regards the politically most pressing issues, notably the UK's continued access to the European Single Market, the post-Brexit status of EU citizens in the UK or the post-Brexit status of UK citizens in the EU. And negotiations about other, less political issues - such as judicial cooperation in civil and commercial matters - have not even begun at the time of writing. ${ }^{5}$ Recently, however, the UK has published two Position Papers that detail the UK's vision for the future of judicial cooperation in civil and commercial matters. ${ }^{6}$ Building on two previously published White Papers, ${ }^{7}$ these sketch how the UK wants to deal with the core issues of choice of law, jurisdiction and recognition and enforcement of foreign judgments after Brexit. ${ }^{8}$ The two papers, however, leave many questions unanswered and ample room for discussion and political manoeuvring. The following article, therefore, sheds light on the most important issues at stake and discusses what the future framework for judicial cooperation in civil and commercial matters could and should look

II', available at <http://ohrh.law.ox.ac.uk/brexit-foundational-constitutional-and-interpretiveprinciples-ii/>.

4 Note that the 'withdrawal' of Greenland from the European Economic Community in 1985 was not the withdrawal of a Member State since Greenland had never been a Member State of the European Economic Community, but part of a Member State (Denmark). Greenland's 'withdrawal' was, therefore, performed through an amendment of the EC Treaty that was ratified by all Member States and that reduced the territorial reach of the EC Treaties. See the Treaty amending, with regard to Greenland, the Treaties establishing the European communities, [1985] OJ L 29/1.

5 See for an overview of the evolving position as regards judicial cooperation A Dickinson, 'Close the Door on Your Way Out' (2017) Zeitschrift für Europäisches Privatrecht 539, 544ff.

6 HM Government, Providing a Cross-Border Civil Judicial Cooperation FrameworkA Future Partnership Paper, available at <https://www.gov.uk/government/publications/ providing-a-cross-border-civil-judicial-cooperation-framework-a-future-partnership-paper $>$ HM Government, Enforcement and Dispute Resolution - A Future Partnership Paper, available at <https://www.gov.uk/government/uploads/system/uploads/attachment_data/file/639609/ Enforcement_and_dispute_resolution.pdf $>$.

7 Department for Exiting the European Union, The United Kingdom's Exit from and New Partnership with the European Union White Paper (London 2017) available at $<$ https://www. gov.uk/government/publications/the-united-kingdoms-exit-from-and-new-partnership-with-theeuropean-union-white-paper\#history $>$ Department for Exiting the European Union, Legislating for the United Kingdom's Withdrawal from the European Union. White Paper (London 2017) available at <https://www.gov.uk/government/uploads/system/uploads/attachment_data/file/ 604516/Great_repeal_bill_white_paper_accessible.pdf $>$.

8 The EU has likewise published a Position Paper on judicial cooperation in civil and commercial matters. However, this paper focuses on the withdrawal agreement and only makes suggestions for transitional provisions. See EU Position Paper on Judicial Cooperation in Civil and Commercial Matters (12 July 2017) TF50 (2017) 9/2 - Commission to UK, available at $<$ https://ec.europa.eu/commission/sites/beta-political/files/essential-principles-civil-commercialmatters_en_0.pdf $>$. 
like. It thereby seeks to make a positive difference in the lives of all the UK and EU citizens, families and businesses, who will continue to work, live, travel and do business abroad after Brexit.

The article is organized in three parts: The first part sketches the current, ie pre-Brexit, European legal framework as regards choice of law, jurisdiction and recognition and enforcement of foreign judgments (Section II). The second part discusses how this framework will change post-Brexit in the absence of any special arrangement between the UK and the EU and in the absence of other (unilateral, bilateral or multilateral) actions of the UK (Section III). The third part then explores how the UK and the EU may avoid the negative consequences of a 'hard Brexit' as described in the second part (Section IV). For reasons of space the article focuses on civil and commercial matters. ${ }^{9}$

\section{STATUS QUO: THE CURRENT STATE OF JUDICIAL COOPERATION IN THE EU}

Ever since the adoption of the Treaty of Amsterdam, ${ }^{10}$ judicial cooperation in cross-border matters has been high on the agenda of the European legislature. On the basis of Article 81 TFEU (ex-Art 61 lit. c), 65 ECT it has - to dateadopted a total of 18 Regulations. Of these 18 Regulations 12 are applicable in the UK, ${ }^{11}$ among them virtually all that relate to civil and commercial matters. ${ }^{12}$ Those in force include, in particular, the Rome I and the Rome II

\footnotetext{
9 See for an overview of the implications of Brexit has for other aspects of judicial cooperation, especially those relating to family matters, A Dutta, 'Brexit and International Family Law from a Continental Perspective' (2017) 29 CFLQ 199; B Hess, 'Back to the Past: BREXIT und das europäische internationale Privat- und Verfahrensrecht' (2016) Praxis des Internationalen Privatund Verfahrensrechts 409, 416ff; R Lamont, 'Not a European Family: Implications of 'Brexit' on International Family Law' (2017) 29 CFLQ 267; E Lein, 'Unchartered Territory? A Few Thoughts on Private International Law post Brexit' (2015) 17 YrbkPrivIntlL 33, 43 and 44ff; J Ungerer, 'Brexit von Brüssel und den anderen Verordnungen zum Internationalen Privat- und Verfahrensrecht' in M Kramme, C Baldus and M Schmidt-Kessel (eds), Brexit und die Juristischen Folgen (Nomos 2017) 296, 307ff. See also The General Council of the Bar, The Brexit Papers (2nd edn, Brexit Working Group March 2017) 39ff, 45ff, $51 \mathrm{ff}$ and 60ff, available at <http://www.barcouncil.org.uk/media/557778/170316_brexit_papers_second_ edition_final_version.pdf $>$ as well as the Report of the European Union Committee of the House of Lords, Brexit: Justice for Families, Individuals and Businesses? (17th Report of Session 2016-17, HL Paper 134, 20 March 2017) 3, 41 para 145, 45 para 32, available at $<$ https://www. publications.parliament.uk/pa/ld201617/ldselect/ldeucom/134/134.pdf> 24ff.

${ }^{10}$ Consolidated version of the Treaty establishing the European Community, [1997] OJ C $340 / 173$.

11 The UK enjoys a special status when it comes to judicial cooperation in civil matters: according to Article 1 of Protocol No 21 to the Treaty on European Union (TEU) and the Treaty on the Functioning of the European Union (TFEU), the UK does not participate in the adoption of any measures taken under Title V of Part Three TFEU ('Area of Freedom, Security and Justice') including measures adopted under Chapter 4 of Title V TFEU ('Judicial cooperation in civil matters'). According to Article 3 of the Protocol the UK may, however, declare on a caseby-case basis, that it wishes to take part in any such measures.

12 The only Regulation in civil and commercial matters the UK has not adopted is Reg (EU) No 655/2014 of the European Parliament and of the Council of 15 May 2014 establishing a European Account Preservation Order procedure to facilitate cross-border debt recovery in civil and commercial matters, [2014] OJ L 189/59.
} 
Regulations ${ }^{13}$ that determine the law applicable to contractual and noncontractual obligations as well as the Brussels Ia Regulation ${ }^{14}$ that deals with jurisdiction, recognition and enforcement of foreign judgments in civil and commercial matters. Also in force are a number of Regulations that are meant to ease the settlement of cross-border disputes more generally but which will not be discussed here. These include the Service Regulation, ${ }^{15}$ the Evidence Regulation, ${ }^{16}$ the Enforcement Order Regulation, ${ }^{17}$ the Small Claims Regulation, ${ }^{18}$ the Payment Order Regulation ${ }^{19}$ and the Insolvency Regulation. ${ }^{20}$ Together, all these Regulations establish a fairly clear and predictable legal framework for the settlement of disputes with a foreign element. This is not the least because courts in the UK will apply the same provisions to determine the applicable law and the competent court as courts in the remaining Member States. And they will apply the same provisions to recognize and enforce foreign judgments.

Now, what will happen with all these Regulations once the UK leaves the EU? Unfortunately, Article 50 TEU doesn't say. Article 50(3) TEU merely provides that the 'Treaties', ie the TEU, the TFEU as well as any Protocols and Annexes, ${ }^{21}$ will cease to apply in the UK from the date of entry into

13 Reg (EC) No 593/2008 of the European Parliament and of the Council of 17 June 2008 on the law applicable to contractual obligations (Rome I), [2008] OJ L 177/6; Regulation (EC) No 864/ 2007 of the European Parliament and of the Council of 11 July 2007 on the law applicable to non-contractual obligations (Rome II), [2007] OJ L 199/40.

${ }^{14}$ Reg (EC) No 44/2001 of 22 December 2000 on jurisdiction and the recognition and enforcement of judgments in civil and commercial matters, [2001] OJ L 12/1, recast through Regulation (EU) No 1215/2012 of the European Parliament and of the Council of 12 December 2012 on jurisdiction and the recognition and enforcement of judgments in civil and commercial matters (recast), [2012] OJ L 351/1.

15 Council Reg (EC) No 1348/2000 of 29 May 2000 on the service in the Member States of judicial and extrajudicial documents in civil or commercial matters, [2000] OJ L 160/37, recast through Regulation (EC) No 1393/2007 of the European Parliament and of the Council of 13 November 2007 on the service in the Member States of judicial and extrajudicial documents in civil or commercial matters (service of documents), and repealing Council Reg (EC) No 1348/ 2000, [2007] OJ EU L 324/79.

16 Council Reg (EC) No 1206/2001 of 28 May 2001 on cooperation between the courts of the Member States in the taking of evidence in civil or commercial matters, [2001] OJ L 174/1.

17 Reg (EC) No 805/2004 of the European Parliament and of the Council of 21 April 2004 creating a European Enforcement Order for uncontested claims, [2004] OJ L 143/15.

18 Reg (EC) No 861/2007 of the European Parliament and of the Council of 11 July 2007 establishing a European Small Claims Procedure, [2007] OJ L 199/1, recast through Reg (EU) 2015/2421 of the European Parliament and of the Council of 16 December 2015 amending Reg (EC) No 861/2007 establishing a European Small Claims Procedure and Reg (EC) No 1896/2006 creating a European order for payment procedure, [2015] OJ L 341/1.

19 Reg (EC) No 1896/2006 of the European Parliament and of the Council of 12 December 2006 creating a European order for payment procedure, [2006] OJ L 399/1.

20 Council Reg (EC) No 1346/2000 of 29 May 2000 on insolvency proceedings, [2000] OJ L 160/1 recast by Reg (EU) No 2015/848 of the European Parliament and of the Council of 20 May 2015 on insolvency proceedings (recast), [2015] OJ L 141/19.

21 Art 1(3), 51 TEU. See also R Aikens and A Dinsmore, 'Jurisdiction, Enforcement and the Conflict of Laws in Cross-Border Commercial Disputes: What Are the Legal Consequences of Brexit?' (2016) 27 EBLR 903, 904ff; O Dörr, in E Grabitz and M Nettesheim (eds), Das Recht der Europäischen Union (CH Beck 2016) art. 50 EUV para. 37. 
force of the withdrawal agreement. However, there is broad agreement that European secondary law will also cease to have direct effect in the UK with the entry into force of the withdrawal agreement. ${ }^{22}$ This is because Article 288 TFEU which provides that regulations and directives shall have binding force in all Member States will cease to apply to and to be binding in relation to the UK on that day. ${ }^{23}$ In addition, the entry into force of the withdrawal agreement will be coupled with the repeal of the European Communities Act $1972^{24}$ which lays the foundation for the UK's membership in the EU and provides in Section (2)1 that '[all] such rights, powers, liabilities, obligations and restrictions ... created or arising by or under the Treaties ... are without further enactment to be given legal effect or used in the United Kingdom ...'.

However, European secondary law will also cease to have direct effect if the UK and the European Union do not manage to negotiate a withdrawal agreement and if the European Communities Act 1972 is not repealed. This is because Article 50(3) TEU provides that the withdrawal will, in this case, become effective and the Treaties will cease to apply within two years after submission of the withdrawal notification referred to in Article 50(2) TEU. ${ }^{25}$ To be sure, one could argue that the European Communities Act 1972, absent a repeal by the UK legislature, will not be affected by the expiration of the twoyear period of Article 50(3) TEU and that, therefore, European secondary law will remain effective and applicable. However, the majority view in the UK is that the European Communities Act 1972 will lose its practical significance because there will be no more rights, powers, liabilities, obligations or restrictions created by or arising under the Treaties in the meaning of Section 2(1) once the Treaties cease to apply pursuant to Article 50(3) TEU. ${ }^{26}$ Against this background, the above mentioned 12 Regulations, and notably the Rome I and II Regulations and the Brussels Ia Regulation, will cease to

22 B Bronger, P Scherer and M Söhnchen, 'Rechtliche Auswirkungen im Fall der Fälle, (2016) Europäisches Wirtschafts- und Steuerrecht 131, 133; R Buckle, T Hewish, JC Hulsman et al., Brexit: Directions for Britain Outside the EU (Institute of Economic Affairs 2015) 22; O Busch, D Gegusch, A Linn et al., 'Scheiden tut weh: Brexit - die steuerlichen und rechtlichen Folgen' (2016) Der Betrieb 1526; Dörr, in Grabitz, Hilf and Nettesheim (n 21) art 50 EUV para 41; Hess (n 9) 410; Lein (n 9) 33; M Pilich, 'Brexit and EU Private International Law: May the UK Stay in?' (2017) Maastricht Journal of European and Comparative Law 1, 9ff; G Rühl, 'Die Wahl englischen Rechts und englischer Gerichte. Zur Zukunft des Justizstandortes England' (2017) JuristenZeitung 72, 73ff; A Thiele, 'Der Austritt aus der EU - Hintergründe und rechtliche Rahmenbedingungen eines 'Brexit"' (2016) Europarecht 281, 301.

${ }^{23}$ Aikens and Dinsmore (n 21) 904; S Masters and B McRae, "What Does Brexit Mean for the Brussels Regime?' (2016) JIntlArb 483, 484ff.

${ }_{24}$ See art 1 European Union (Withdrawal) Bill of July 2017.

25 Note, however, that art 50(3) TEU allows the European Council in agreement with the Member State concerned, to extend this period by unanimous vote.

26 Aikens and Dinsmore (n 21) 904; H Hestermeyer, 'How Brexit Will Happen: A Brief Primer on European Union Law and Constitutional Law Questions Raised by Brexit' (2016) JIntlArb 429, 440 ('lose their effect', 'indirect nullification'); N Barber, T Hickman and J Kifng, 'Pulling the Article 50 “Trigger": Parliament's Indispensable Role' ('render it nugatory', 'dead letter') available at <https://ukconstitutionallaw.org/2016/06/27/nick-barber-tom-hickman-and-jeff-kingpulling-the-article-50-trigger-parliaments-indispensable-role/ $>$. 
have direct effect in the UK once Brexit becomes effective. ${ }^{27}$ By the same token they will cease to apply in the remaining Member States if and to the extent that they do not cover cases involving third States. ${ }^{28}$

\section{THE BASELINE: CONSEQUENCES OF A 'HARD BREXIT' FOR JUDICIAL COOPERATION}

The above analysis triggers the question of which provisions will take the place of the Rome I, the Rome II and the Brussels Ia Regulations once a withdrawal agreement enters into force. The answer to this question depends, of course, on the steps the UK and the EU will take (unilaterally, bilaterally or multilaterally) to fill the void. However, before discussing the various options that the UK and the EU have in this respect (Section IV), I will analyse what will happen if the UK leaves the EU without any special arrangement as regards choice of law, jurisdiction and recognition and enforcement. To be sure, in the light of the recently published UK Position Papers, and especially the UK government's plan to convert some of the above-mentioned European Regulations into English law by way of the European Union (Withdrawal) Bill, ${ }^{29}$ this scenario is not the most likely. However, analysing what happens if nothing happens shows what is at stake - and why both the UK and the EU have an interest in avoiding a 'hard Brexit' in the field of judicial cooperation. In the following sections I will first discuss whether international Conventions, notably the Rome and the Brussels Conventions which were applicable in the UK and some EU Member States prior to the unification of private international law in the EU, may revive and become applicable again after Brexit (Section III. A). Then I will analyse which national provisions might take the place of the Rome I, the Rome II and the Brussels Ia Regulations (Section III.B-D)

\section{A. Revival of the Rome and the Brussels Conventions?}

The unification of private international law on the European level is a rather recent phenomenon. It only became possible following the entry into force of the Treaty of Amsterdam in $1999,{ }^{30}$ which conferred near to full competence for private international law on the European legislature. Prior to that the Member States achieved judicial cooperation in civil and commercial matters by way of international treaties. In 1968 they agreed on the Brussels Convention on

\footnotetext{
27 Aikens and Dinsmore (n 21) 904ff; G Croisant, 'Fog in Channel - Continent Cut Off. Les conséquences juridiques du Brexit pour le droit international privé et l'arbitrage international' (2017) Journal des tribunaux 24, 26; A Dickinson, 'Back to the Future: The UK's EU Exit and the Conflict of Laws' (2016) 12 JPrivIntlL 195, 197ff; M Lehmann and N D'Souza, 'What Brexit Means for the Interpretation and Drafting of Financial Contracts' (2017) 32 JIBFL 101, 101 and 103; Masters and McRae (n 23) 483ff; Pilich (n 22) 10.

${ }^{28}$ Croisant (n 27) 26. See for the details Section III.

29 See arts 2 and 3 European Union (Withdrawal) Bill of July 2017.

30 Treaty of Amsterdam amending the Treaty on European Union, the Treaties establishing the European Communities and certain related acts, [1997] OJ C 340/1.
} 
jurisdiction and recognition and enforcement of foreign judgments, ${ }^{31}$ and in 1980 they adopted the Rome Convention on the law applicable to contractual obligations. ${ }^{32}$ Both Conventions were never formally cancelled after entry into force of the Rome I and the Brussels I Regulation. Therefore, a number of authors have recently suggested that they may revive and (re-)gain application after Brexit. ${ }^{33}$ This suggestion is interesting - and surprising - in and of itself because there is broad agreement that a return to both Conventions is not really desirable. ${ }^{34}$ The Brussels Convention, for example, does not reflect the substantial improvements which the conversion into the Brussels I Regulation of 2001 and the recast of 2012 have brought about. ${ }^{35}$ Moreover, its geographical reach is limited since it does not extend to Member States who joined the European Union after its conversion into the Brussels I Regulation. ${ }^{36}$ But be it as it may: the above-mentioned authors argue that neither the Rome nor the Brussels Convention were ever formally cancelled. And since the Rome I and the Brussels Ia Regulation require their application as regards some overseas territories ${ }^{37}$ they conclude that both the Rome and the Brussels Conventions are still alive.

The problem with this view, however, is not only that it would lead to application of provisions that are widely considered as outdated, but that it would also result in the application of the Rome and the Brussels Convention in a non-Member State-even though both Conventions were never meant to apply in non-Member States and even though only Member States were allowed to accede. ${ }^{38}$ Of course, the UK was a Member State of the European Community at the time of signing the Conventions. However-and contrary

31 Brussels Convention on jurisdiction and the enforcement of judgments in civil and commercial matters, [1972] OJ C 299/32. Note that the Convention was amended several times following the accession of new Member States to the European Community.

32 Rome Convention on the law applicable to contractual obligations, [1980] OJ L 266/1.

33 Aikens and Dinsmore (n 21) 908ff; Dickinson (n 27) 202; Lehmann and D'Souza (n 27) 101 and 103; M Lehmann and D Zetzsche, 'Brexit and the Consequences for Commercial and Financial Relations between the EU and the UK' (2016) 27 EBLR 999, 1004ff and 1023ff; Lein (n 9) 38; M Lehmann and D Zetzsche, 'Die Auswirkungen des Brexit auf das Zivil- und Wirtschaftsrechts' (2017) JuristenZeitung 52, 65, 70; Masters and McRae (n 23) 491ff (as regards the Brussels Convention); Ungerer (n 9) $298 \mathrm{ff}$.

34 Lehmann and Zetzsche (2016) (n 33) 1024; Lehmann and Zetzsche (2017) (n 33) 65, 70; Lein (n 9) 38; Masters and McRae (n 23) 492ff. See also the Report of the Justice Committee of the House of Commons, Implications of Brexit for the Justice System, (Ninth Report of Session 2016-17, HC 750, 22 March 2017) 15 para 28 available at <https://www.publications.parliament.uk/pa/ $\mathrm{cm} 201617 / \mathrm{cmselect} / \mathrm{cmjust} / 750 / 750$.pdf $>$.

35 The Brussels Convention was last amended in 1996 following the accession of Austria, Finland and Sweden. See Brussels Convention on jurisdiction and the enforcement of judgments in civil and commercial matters (consolidated version), [1998] OJ C 27/1.

${ }^{36}$ In fact, a total of 13 Member States (Bulgaria, Croatia, Cyprus, the Czech Republic, Estonia, Hungary, Latvia, Lithuania, Malta, Poland, Romania, Slovenia and Slovakia) never signed the Brussels Convention because they joined the EU after the entry into force of the Brussels I Regulation. See, however, Aikens and Dinsmore (n 21) 909ff who argue that the just-mentioned Member States agreed to be bound by the Brussels Convention with the accession to the EU.

37 Art 24 Rome I Regulation; art 68 Brussels Ia Regulation.

38 Art 28 Rome Convention; art 63 Brussels Convention. 
to what the above-mentioned authors claim ${ }^{39}$-membership in the European Union or the European Community was not merely a requirement for joining the Convention but a permanent condition for being a contracting State. ${ }^{40}$ This follows not only from the genealogy of the Convention but also from its preamble, which stresses the need for further unification of law within the European Community, ie among Member States. ${ }^{41}$

In addition, when the Member States decided to convert the Rome and the Brussels Conventions into the Rome I and the Brussels I Regulation they never had a revival of the old Conventions in mind. ${ }^{42}$ As follows clearly from Article 24 Rome I Regulation and Article 68 Brussels I Regulation (now: Article 68 Brussels Ia Regulation), both Regulations were meant to fully replace the Rome and the Brussels Convention as between those (then-)Member States participating in the Rome I and the Brussels I Regulations. Continued application of the Conventions was clearly limited to Denmark and some overseas territories. ${ }^{43}$ This implies that the Rome and Brussels Conventions were not merely suspended with the entry into force of the Rome I and the Brussels I Regulation, but terminated under public international law. ${ }^{44}$ This termination was, of course, partial: both Conventions remained alive and applicable as regards the overseas territories mentioned in Article 24 Rome I Regulation and Article 68 Brussels I Regulation (now Article 68 Brussels Ia Regulation) as well as regards Denmark. But as regards the other (then-)Member States they were terminated.

Doctrinally this view may be based on general principles of international law, notably the principle of consensual termination of international treaties. This principle is, for example, enshrined in Article 54 lit. b) of the Vienna Convention on the Law of Treaties of $1969^{45}$ and allows the contracting States to terminate an international treaty at any time by consent of all the parties after consultation with the other contracting States. If, however, the Vienna Convention on the Law of Treaties allows the contracting States to completely terminate a treaty it must also be possible for the contracting States to agree on a partial termination, ie a termination only between some contracting States. As regards the Rome and the Brussels Convention the contracting States participating in the Rome I and the Brussels I Regulation agreed that these Regulations would fully replace the Rome and the Brussels Convention. And as follows clearly from Protocol No 22 on the Position of

39 Dickinson (n 27) 203ff; Lehmann and D’Souza (n 27) 101; Lehmann and Zetzsche (2016) (n 33$)$ 1004; Lehmann and Zetzsche (2017) (n 33) 64 and 71.

${ }^{40}$ Hess (n 9) 409, 417; Rühl (n 22) 75 and 77. In a similar vein Croisant (n 27) 28; Pilich (n 22) $13 \mathrm{ff}$.

42 Croisant (n 27) 28; Rühl (n 22) 75 and 77.

43 Croisant (n 27) 28; Hess (n 9) 417; Rühl (n 22) 75 and 77.

44 Croisant (n 27) 28; Hess (n 9) 417; Rühl (n 22) 75 and 77. See also Pilich (n 22) $13 \mathrm{ff}$.

45 Vienna Convention on the Law of Treaties of 23 May 1969, 1155 UNTS 331. 
Denmark, Denmark consented to this. ${ }^{46}$ So, all contracting parties to the Rome and the Brussels Convention, including Denmark, agreed to terminate it partially in the above-described sense. ${ }^{47}$ As a consequence they cannot revive after Brexit. ${ }^{48}$

Application of the Rome and the Brussels Conventions, however, also fails if one does not follow the above view and if one assumes that both Conventions were not partially terminated with the entry into force of the Rome I and the Brussels I Regulation: both Conventions form part of the acquis communitaire in a wider sense. ${ }^{49}$ As such they cannot remain unaffected by the withdrawal of a Member State from the EU pursuant to Article 50 TEU. In fact, as Burkhard Hess has recently argued, they will be terminated on the day of Brexit because Article 50(3) TEU must be classified as a special provision providing for consensual termination of the Rome and the Brussels Conventions in the meaning of Article 54 lit. b) of the Vienna Convention on the Law of Treaties. ${ }^{50}$ In any event, it is likely that Brexit amounts to a fundamental change of circumstances in the meaning of Article 62 of the Vienna Convention, thus, allowing the remaining Member States to withdraw from the Conventions after Brexit. ${ }^{51}$ Alternatively, one might consider applying Article 63 of the Vienna Convention by analogy. So, even if the Rome and the Brussels Conventions were not terminated either with the entry into force of the Rome I and the Brussels I Regulations or on the day of Brexit, they would not, at least not as a matter of public international law, fill the void left by the Rome I and the Brussels Ia Regulation after Brexit. ${ }^{52}$ The question is, then: which provisions will fill the void if the UK and the EU do not take any (unilateral, bilateral or multilateral) steps?

\section{B. Legal Framework as Regards Choice of Law}

\section{Applicable (default) provisions}

As regards choice of law the situation will be rather straightforward. In the UK the Rome II Regulation will be replaced by Part III of the UK Private International Law (Miscellaneous Provisions) Act of $1995 .{ }^{53}$ To the extent that the UK Private International Law (Miscellaneous Provisions) Act 1995 does not contain any choice-of-law rules, which holds true, for example, for

\footnotetext{
46 In the preamble, the Protocol specifically notes: 'Denmark will not prevent the other Member States from further developing their cooperation with respect to measures not binding on Denmark.'

47 Rühl (n 22) 75 and 77.

48 Rühl (n 22) 75 and 77. Likewise as regards the Brussels Convention, A Staudinger, 'Gedankensplitter zum Brexit', jurisPR-IWR 5/2016 Anm. 1.

49 Prior to adoption of the Rome I and the Brussels I Regulation new Member States, therefore, had to sign them before being allowed to join the EU.

${ }^{50}$ Hess (n 9) 417. Likewise Croisant (n 27) 28; Rühl (n 22) 75 and 77.

51 Likewise Lein (n 9) 38 and 43; Rühl (n 22) 75 (fn 44) and 77. $\quad{ }^{52}$ Lein (n 9) 38.

53 Aikens and Dinsmore (n 21) 916ff; Croisant (n 27) 31; Dickinson (n 27) 198ff, 202 (fn 48); Lehmann and D'Souza (n 27) 101.
} 
the tort of defamation and unjust enrichment, the traditional rules of the common law will step in. ${ }^{54}$ As regards contractual obligations, the Contracts (Applicable Law) Act 1990 will apply. And since the Contracts (Applicable Law) Act 1990 calls for application of the Rome Convention to the extent the Rome I Regulation does not apply, UK courts will have to resort to the Rome Convention to determine the applicable contract law after Brexit. Of course, this comes as a surprise given that the Rome Convention was (partially) terminated under public international law. However, the UK belongs to those countries where application of international treaties requires implementation by the national legislature. ${ }^{55}$ To the extent that international treaties have been implemented they must, therefore, be applied by national courts no matter what their status is under public international law. If the Rome I Regulation ceases to apply as a result of Brexit, the Rome Convention will, therefore, revive and become applicable before UK courts as a matter of UK national law. ${ }^{56}$

In the remaining Member States, the situation likewise seems to be straightforward: Both the Rome I and the Rome II Regulation are based on the principle of universal application. ${ }^{57}$ Therefore, they apply to all cases with a foreign element irrespective of whether the foreign element relates to a Member State or a third State. As a consequence one is tempted to assume that courts in the remaining Member States will apply the Rome I Regulation as regards contractual obligations and the Rome II Regulation as regards noncontractual obligations. And while this is generally accepted to be true in the context of non-contractual obligations, ${ }^{58}$ the case of Denmark teaches us that things are more complicated when it comes to contractual obligations. ${ }^{59}$ As indicated earlier, Denmark does not take part in any measures relating to judicial cooperation in civil and commercial matters. Therefore, the Rome I Regulation does not have to be applied by Danish courts ${ }^{60}$ _ just like the Rome I Regulation does not have to be applied by UK courts after Brexit. It is, however, unclear which legal instruments courts in other Member States

\footnotetext{
54 Lehmann and D'Souza (n 27) 101; Lehmann and Zetzsche (2016) (n 33) 1009; Lehmann and Zetzsche (2017) (n 33) 67; Rühl (n 22) $75 . \quad \quad \quad{ }^{55}$ See, for example, Dickinson (n 27) 201.

56 Aikens and Dinsmore (n 21) 916; Dickinson (n 27) 202. See also Croisant (n 27) 31; MSA Wahab, 'Brexit's Chilling Effect on Choice of Law and Arbitration in the United Kingdom: Practical Reflections Between Aggravation and Alleviation' (2016) JIntlArb 463, 464ff.

57 Art 2 Rome I Reg; art 3 Rome II Reg.

58 See, for example, Croisant (n 27) 31; Hess (n 9) 417; Lehmann and D’Souza (n 27) 101; Lehmann and Zetzsche (2016) (n 33) 1009; Lehmann and Zetzsche (2017) (n 33) 66; Lein (n 9) 42.

59 See for a detailed account WH Roth, 'Maßgebliche Kollisionsnormen im deutsch-dänischen Rechtsverkehr', (2015) Praxis des Internationalen Privat- und Verfahrensrechts 222ff; J von Hein, 'Konflikte zwischen völkerrechtlichen Übereinkommen und europäischem Sekundärrecht auf dem Gebiet des Internationalen Privatrechts' in M Ruffert (ed), Festschrift für Meinhard Schröder (Duncker \& Humblot 2012) 29, 38ff.

60 O Lando and PA Nielsen, 'The Rome I Regulation' (2008) 45 CMLRev 1687, 1689; S Leible and M Lehmann, 'Die Verordnung über das auf vertragliche Schuldverhältnisse anzuwendende Recht ('Rom I')' (2008) Recht der Internationalen Wirtschaft 528, 532.
} 
have to apply to determine the applicable contract law if the case has a relationship to Denmark. Some courts and scholars take the view that the Rome Convention-and not the Rome I Regulation-applies in cases relating to Denmark. ${ }^{61}$ They argue that the Rome Convention was never formally cancelled and that it, therefore, takes precedence over the Rome I Regulation by virtue of Article 25 of the Regulation. ${ }^{62}$ If one assumescontrary to the position taken in this article - that the Rome Convention was not (partially) terminated with the entry into force of the Rome I Regulation one might, therefore, be inclined to hold the Rome Convention applicable in cases having a relation to the UK after Brexit. ${ }^{63}$ However, even as regards cases with a relation to Denmark, the majority of scholars advocate application of the Rome I Regulation over application of the Rome Convention. ${ }^{64}$ They argue that the Rome I Regulation is universally applicable and, therefore, applies to all cases with connections to foreign countries - and not only to cases with connections to Member States. In addition, they argue that Article 25 Rome I Regulation does not apply to the relationship between the Rome I Regulation and the Rome Convention because that relationship is exclusively regulated by Article 24 Rome I Regulation. ${ }^{65}$ Even if one were to assume that the Rome Convention was not terminated with the entry into force of the Rome I Regulation, courts in the remaining EU Member States would, therefore, have to apply the Rome I Regulation in cases relating to the UK. ${ }^{66}$ This view is supported by the fact that a number of Member States, among them Germany, repealed the national provisions implementing the Rome Convention with the entry into force of the Rome I Regulation. National legislatures, thus, apparently assumed that there would be no room for application of the Rome Convention after the entry into force of the Rome I Regulation.

\section{Consequences}

As a consequence of the preceding analysis, issues of choice-of-law will be subject to different legal regimes depending on whether a suit is brought in the UK or in the remaining Member States. If the UK and the EU do not take any steps to deal with choice of law post-Brexit, courts in the EU will continue

61 OLG Koblenz (Court of Appeals), 19 September 2012 - 2 U 1050/11 (2015) Praxis des internationalen Privat- und Verfahrensrechts 255, 256ff; E Brödermann and G Wegen, in $\mathrm{H}$ Prütting, G Wegen and G Weinreich (eds), Bürgerliches Gesetzbuch (11th edn, Luchterhand 2016) art 2, para 3 as well as art 25, para 2ff; Lein (n 9) 42; Roth (n 59) 224; A Staudinger, 'Rechtsvereinheitlichung innerhalb Europas: Rom I und II', (2008) Anwaltsblatt 8.

62 Roth (n 59) 224 and 225.

63 Lehmann and Zetzsche (2016) (n 33) 1005; Lehmann and Zetzsche (2017) (n 33) 64ff; Lein (n 9) 42.

${ }^{64}$ H Hoffmann, 'Article 24' in G-P Calliess (ed), Rome Regulations (2nd edn, Kluwer 2015) para 3; von Hein (n 59) 39ff; Lando and Nielsen (n 60) 1689ff; Leible and Lehmann (n 60) 532.

${ }^{65}$ Hess (n 9) 417. 
to apply the Rome I and II Regulations, whereas courts in the UK will resort to the Contracts (Applicable Law) Act and, thus, to the Rome Convention as regards contractual obligations and to Part III of the Private International Law (Miscellaneous Provisions) Act 1995 in combination with the rules of the common law as regards non-contractual obligations. Of course, the practical effects of this finding depend on the extent to which these regimes actually differ. ${ }^{67}$ However, no deep comparative inquiry is necessary to say that there will be differences. Take, for example, choice-of-law clauses which would otherwise offer a good means for creating legal certainty. Here, Article 14 Rome II Regulation allows commercial parties to choose the law applicable to non-contractual obligations whereas the Private International Law (Miscellaneous Provisions) Act 1995 and the common law do not clearly bestow any such right on the parties. ${ }^{68}$ In addition, the Rome I Regulation contains separate provisions for insurance contracts and carriage contracts which restrict the use of choice-of-law clauses vis-à-vis policyholders and passengers in ways unknown to the Rome Convention. ${ }^{69}$ By the same token, the Rome I Regulation restricts choice-of-law clauses in consumer contracts in a much more complex fashion than the Rome Convention..$^{70}$ And, finally, the Rome I Regulation limits the effects of a choice-of-law clause in purely European Union cases ${ }^{71}$ and provides for a new rule on the application of (foreign) overriding mandatory provisions. ${ }^{72}$

Differences between the applicable legal regimes, however, will not be the only source of uncertainty that parties will face following Brexit if the UK and the EU refrain from taking any steps. Further uncertainty will arise because it is unclear when the applicable legal regime will actually change in the UK, ie when UK courts will actually stop applying the Rome Regulations. Of course, as indicated previously both Regulations will cease to have effect in the UK on the day Brexit becomes effective. However, it is unclear whether this means that UK courts will have to apply the Private International Law Act and the Rome Convention from that very day-or whether they may or must continue applying the Rome Regulations for a transitional period, notably to choice-of-law clauses concluded prior to Brexit. ${ }^{73}$ For obvious reasons, neither the Rome I nor the Rome II Regulation provides clear-cut answers. However, the Homawoo judgment of the ECJ tells us that the Rome II Regulation applies to all events giving rise to damage that

\footnotetext{
67 See for a short overview of the differences Lehmann and Zetzsche (2016) (n 33) 1006; Lehmann and Zetzsche (2017) (n 33) 65; Wahab (n 56) 464ff and 469ff.

68 A Briggs, 'When in Rome, Choose as the Romans Choose' (2009) 125 LQR 191, 193. See for a nuanced and detailed discussion of whether and to what extent the common law and the Private International Law (Miscellaneous Provisions) Act 1995 allow for a choice of law as regards noncontractual obligations; A Briggs, 'Agreements on Jurisdiction and Choice of Law (Oxford University Press 2008) 403ff, para 10.43ff.

70 Art 6 Rome I Regulation.

72 Art 9(3) Rome I Regulation.

69 Arts 5 and 7 Rome I Regulation.

71 Art 3(4) Rome I Regulation.

73 See also Dickinson (n 27) $207 \mathrm{ff}$.
} 
occur after its entry into force on 11 January $2009 .{ }^{74}$ This could be understood to mean that a choice of law concerning non-contractual obligations will be governed by the Rome II Regulation even after Brexit if the event giving rise to damage occurs before the Regulation ceases to be in force in the UK, ie before Brexit. ${ }^{75}$ As a consequence, Article 14 Rome II Regulation would apply even after Brexit, if the choice-of-law clause relates to events giving rise to damage occurring on or after 11 January 2009 but before the day of Brexit. And Article 3 Rome I Regulation would apply if the choice-of-law clause relates to a contract concluded between 17 December 2009 and the day of Brexit.

The advantage of this view is obvious: choice-of-law clauses would be subject to the same legal provision no matter when legal proceedings were commenced. However, the problem with this view is equally obvious: it would require UK courts to apply the Rome II Regulation - and for what it is worth the Rome I Regulation - for quite some time after Brexit, ie after European secondary law has ceased to have direct effect in the UK. It is, therefore, unclear whether the ECJ or UK courts would actually accept that interpretation. For the parties this means that they will have to live with a substantial degree of uncertainty. Absent a clear provision in the withdrawal agreement, they will have to accept that they will not be able to know at the time of choosing the applicable law which regime will eventually govern their choice of law should they end up in UK courts. ${ }^{76}$ This is particularly dramatic for choiceof-law clauses concerning non-contractual obligations because the common law and the UK Private International Law (Miscellaneous Provisions) Act 1995 - in contrast to the Rome II Regulation - do not clearly allow the parties to choose the applicable law. ${ }^{77}$

\section{Legal Framework as Regards Jurisdiction}

\section{Applicable (default) provisions}

As regards jurisdiction, UK courts will likewise have to resort to UK national law after Brexit in the absence of any specific arrangement providing otherwise. This is because the Brussels Convention of 1968 would be inapplicable. ${ }^{78}$ Nor

74 ECJ (17 November 2011) C-412/10 - Deo Antoine Homawoo v GMF Assurances SA, ECR 2011, I-11622, para 37.

75 Dickinson (n 27) 209.

${ }^{76}$ Note, however, that both the UK and the EU have recently suggested that the Rome I and II Regulations should continue to apply to contracts concluded before the withdrawal date and to events which occurred before the withdrawal date. See HM Government, Providing a CrossBorder Civil Judicial Cooperation Framework. A Future Partnership Paper (n 6) 10 para 7 and the EU Position Paper on Judicial Cooperation in Civil and Commercial Matters (n 8) 2.

77 See (n 68).

78 See Section III.A. It is also submitted that the Brussels Convention, in contrast to the Rome Convention, does not apply as a matter of UK national law. This is because Section 1(4) of the implementing act, the Civil Jurisdiction and Judgments Act 1982, refers to the Brussels Ia Regulation and leaves it to Article 68 to determine whether the Brussels Regulation or the Brussels Convention applies. As indicated earlier Article 68, however, must be understood to 
would other international conventions, notably the Lugano Conventions of 1988 and 2007 and the Hague Choice of Court Convention of 2005. ${ }^{79}$ As regards the Lugano Convention of 2007 and the Hague Choice of Court Convention of 2005, this follows from the fact that the UK itself is not a party to these Conventions. ${ }^{80}$ Both were signed by the EU within its competence to conclude international treaties on behalf of the Member States. Therefore, the UK is bound to the conventions only pursuant to Article 216(2) TFEU. As soon as Brexit becomes effective, Article 216(2) TFEU and, hence, the Lugano Convention of 2007 and the Hague Convention of 2005 will cease to apply in the UK as a matter of European law. The situation is somewhat different as regards the Lugano Convention of 1988. That Convention is the predecessor of the Lugano Convention of 2007 and was not signed by the EU, but by the Member States themselves, including the UK. However, the problem with the Lugano Convention of 1988 is that it was fully replaced by the Lugano Convention of 2007 and, hence, terminated in accordance with Article 59 of the Vienna Convention on the Law of Treaties. ${ }^{81}$

In the remaining Member States international jurisdiction will continue to be governed by the Brussels Ia Regulation to the extent that it applies to third States, which is, for example, the case if the defendant has its domicile in a EU Member State or if a consumer domiciled in a EU Member State sues a professional domiciled in the UK. In all other cases the Member State courts will apply their own national rules of jurisdiction.

\section{Consequences}

The consequences of the preceding analysis are straightforward: in the absence of any specific arrangement as regards jurisdiction, determination of the competent court will become more difficult because different legal regimes will apply depending on where proceedings are eventually instituted. And just like choice-of-law clauses will not be able to overcome the uncertainty

mean that the Brussels Convention remains in force only as regards some overseas territories whereas it was terminated as between the Member States participating in the Brussels I Regulation. See, however, for the opposite view Aikens and Dinsmore (n 21) 907ff; Dickinson (n 27) $202 \mathrm{ff}$ and $204 \mathrm{ff}$.

79 M Ahmed and P Beaumont, 'Exclusive Choice of Court Agreements: Some Issues on the Hague Convention on Choice of Court Agreements and Its Relationship with the Brussels I Recast Especially Anti-Suit Injunctions, Concurrent Proceedings and the Implications of BREXIT' (2017) 13 JPrivIntL 386, 409. See for a detailed account Rühl (n 22) $77 \mathrm{ff}$.

80 Aikens and Dinsmore (n 21) 912; Croisant (n 27) 28; Hess (n 9) 409; Lehmann and D'Souza (n 27) 103; Lehmann and Zetzsche (2016) (n 33) 1025; Lehmann and Zetzsche (2017) (n 33) 70ff; Lein (n 9) 39 and 40; Masters and McRae (n 23) 488; Rühl (n 22) 77ff and 79.

81 Croisant (n 27) 29; Dickinson (n 27), 207; Hess (n 9) 409; Lehmann and Zetzsche (2016) (n 33) 1025; Lehmann and Zetzsche (2017) (n 33) 70; Masters and McRae (n 23) 493; Rühl (n 22, 78. Likewise Aikens and Dinsmore (n 21) 912 (but expressing doubts as to whether the adoption of a treaty by the EU on behalf of the Member States may actually lead to termination of a Convention previously signed by the Member States). 
associated with a 'hard' Brexit, choice-of-forum clauses will not do the trick. Assume for example that the parties confer jurisdiction upon UK courts, but one party later commences proceedings in the courts of one of the remaining Member States. In this case, unless the Brussels Ia Regulation applies by way of exception, courts will turn to their own law to determine whether they have jurisdiction. And this will include a consideration of the derogative effect of the choice-of-forum clauses, ie the question of whether the parties have validly opted out of the jurisdiction of a Member State. To be sure, a number of authors suggest-with good arguments-that Article 25 Brussels Ia Regulation and, hence, a uniform regime should be applied to answer this question. ${ }^{82}$ However, the ECJ has adopted this view only in a single case relating to an employment contract. ${ }^{83}$ In all other cases the ECJ has - at least thus far-adhered to a decision of 2000 in which the court refused to apply Article 17 of the Brussels Convention, the pre-predecessor of Article 25 Brussels Ia Regulation, to the choice of non-Member State courts and held national law applicable. ${ }^{84}$

This, however, is not the end of the story. Further uncertainty will be added after Brexit because the parties may no longer trust that courts of Member States will stay proceedings that are instituted in violation of a choice forum clause designating UK courts. ${ }^{85}$ This is because the newly introduced Article 31(2) Brussels Ia Regulation (recast) applies only between the courts of Member States. If one party commences proceedings in a Member State despite the parties having previously agreed on a choice of UK courts, the Member State court seized is not required to stay its proceedings to allow UK courts to go forward. Instead, Article 33 Brussels Ia Regulation (recast) applies which provides Member States with discretion to stay its proceedings if the court of the non-Member State has been seized first and is expected to render a decision that is capable of recognition and enforcement in that Member State.

${ }^{82}$ R Geimer, 'Neues und Altes im Kompetenzsystem der reformierten Brüssel I-Verordnung' in J Adolphsen, J Goebel, U Haas et al. (eds), Festschrift für Peter Gottwald (CH Beck 2014) 175, 178; $\mathrm{H}$ Linke and W Hau, Internationales Zivilverfahrensrecht (6th edn, Otto Schmidt 2015) para 6.8; Hess (n 9) 411; U Magnus, 'Gerichtsstandsvereinbarungen unter der reformierten EuGVO' in N Witzleb, R Ellger, P Mankowski et al. (eds), Festschrift für Dieter Martiny (Mohr Siebeck 2014) 785,789 . In a similar vein J Kropholler and J von Hein, Europäisches Zivilprozessrecht (9th edn, Verlag Recht und Wirtschaft 2011) art 23 EuGVO, para 14; J von Hein, 'Kapitalanlegerschutz im Verbrauchergerichtsstand zwischen Fernabsatz und konventionellem Vertrieb: Zur Konkretisierung der "Ausrichtung" in Art. 15 Abs. 1 lit. c EuGVO' (2006) Praxis des Internationalen Privat- und Verfahrensrechts 16, 17; D Leipold, 'Neues zum Verhältnis zwischen dem Europäischen Zivilprozessrecht und dem einzelstaatlichen Recht - die Bestimmungen der EuGVVO 2012 zur Zuständigkeit für Klagen gegen Parteien mit Wohnsitz in Drittstaaten und zur Beachtung der Rechtshängigkeit in Drittstaaten' in C Meller-Hannich, L Hartzlein, HF Gaul et al. (eds), Festschrift für Eberhard Schilken (CH Beck 2015) 353, 358.

${ }^{83}$ ECJ (19 July 2012) C-154/11 - Mahamdia v Demokratische Volksrepublik Algerien, ECLI: EU:C:2012:491, para 58ff.

${ }^{84}$ ECJ (9 November 2000) C-387/89 - Coreck Maritime GmbH v Handelsveem B.V., ECR 2000, I-9362 para 19.

${ }^{85}$ Hess (n 9) Rühl (n 22) 80. See also The General Council of the Bar (n 9) 32. 
Finally, just as with choice-of-law clauses, uncertainty will arise before UK courts because it is not entirely clear when exactly when the applicable legal regime will change. Again the question is whether UK courts will stop applying the recast Brussels Ia Regulation from the day of Brexit or whether they will continue to apply the recast Brussels Regulation even after the day of Brexit. To be sure, there are good arguments that the Brussels Ia Regulation requires application even after the UK's withdrawal from the EU. ${ }^{86}$ After all, the ECJ has held that choice-of-forum clauses will be subject to the recast Brussels Ia Regulation if they are the subject of proceedings instituted after the entry into force of the Regulation on 10 January 2015. ${ }^{87}$ Applied to the Brexit-scenario this judgment could, therefore, be understood to mean that the Brussels Ia Regulation will apply to choice-of-forum clauses if proceedings start before the day of Brexit. However, it is unclear whether UK courts - or the ECJ-will actually adopt that interpretation. Absent a clear arrangement in the withdrawal agreement, the parties will, therefore, not know which legal regime will govern their choice-of-law clause at the time when they agree on the competent court because parties normally do not know when legal proceedings will be instituted in the future. ${ }^{88}$

\section{Legal Framework as Regards Recognition and Enforcement}

\section{Applicable (default) provisions}

This leads to recognition and enforcement of foreign judgments. Both aspects are currently governed by the Brussels Ia Regulation, which has famously established a system of direct enforcement as between the Members States. ${ }^{89}$ After Brexit and in the absence of any specific arrangement this system will cease to apply in the UK which means that the UK will not be required to recognize and enforce judgments from other Member States without any further steps. It is, however, again unclear which provisions will replace the recast Brussels Ia Regulation. As indicated earlier, neither the Brussels Convention of 1968 nor other international conventions will automatically apply after Brexit. However, the UK is party to six bilateral treaties concluded in the 20th century with Austria, Belgium, France, Germany, Italy and the Netherlands. ${ }^{90}$ Of course, these were later replaced by the Brussels Convention and then by the Brussels I Regulation. But since they were never

86 Dickinson (n 27) 207ff; Hess (n 9) 411.

87 ECJ (13 November 1979) 25/79 - Sanicentral GmbH. v René Collin, ECR 1979, 3424, para. 7 .

${ }^{88}$ Note, however, that both the UK and the EU have recently suggested that choices of forum made prior to the withdrawal date should continue to be assessed against the provisions of European Union law applicable on the withdrawal date. See HM Government, Providing a Cross-Border Civil Judicial Cooperation Framework. A Future Partnership Paper (n 6) 11 para 7 and the EU Position Paper on Judicial Cooperation in Civil and Commercial Matters (n 8) 2.

89 See arts 39ff Brussels Ia Regulation. $\quad 90$ See the list in art 69 Brussels I Regulation. 
formally cancelled, a number of authors argue that they will revive once the UK leaves the EU. ${ }^{91}$ This view, however, shares similar weaknesses as the view that the Rome and the Brussels Conventions will revive after Brexit: nobody had a revival of the old treaties in mind, and everybody considered them to have become obsolete with the entry into force of the Brussels Convention and, later, the Brussels I Regulation. At least to the extent that there is an overlap in the scope of application of, on the one hand, the old treaties and, on the other, the Brussels Convention and the Brussels I Regulation it therefore seems more convincing to assume that they were terminated between the contracting States. ${ }^{92}$ If one follows this view, recognition and enforcement of (all) Member States judgments will be governed by UK national law after Brexit. $^{93}$

In the remaining Member States the situation will be similar. Since application of the Brussels Ia Regulation is limited to judgments from Member States, the direct enforcement system will not apply to UK judgments after Brexit absent a specific agreement to the contrary. And to the extent that neither multilateral nor bilateral international treaties are applicable, recognition and enforcement of UK judgments will be governed by the national laws of the Members States, ie by 27 potentially different national laws. ${ }^{94}$

\section{Consequences}

In the light of the preceding analysis it goes without saying that a 'hard' Brexit will dramatically change the legal landscape for having a judgment enforced abroad. This is because the applicable default provisions do away with the current system of direct enforcement and require judgment creditors to sue on the judgment prior to enforcement. ${ }^{95}$ Cross-border enforcement of judgments will, then, become more cumbersome, more expensive and more uncertain. This holds particularly true if a party wants to have an English judgment enforced in another Member State. For the enforcement of English judgments will require that party to apply for enforcement in every single Member State according to the (national) provisions applicable in that Member State.

However, legal uncertainty will also increase because-just as with choice of law and jurisdiction - it is unclear when precisely the enforcement provisions of the Brussels Ia Regulation will cease to be applicable. Assume, for example, that a party seeks recognition and enforcement of a judgment which was rendered after the day of Brexit but based on proceedings that were initiated on or after 10 January 2015, ie on or after the day the Brussels Ia Regulation

\footnotetext{
91 Croisant (n 27) 29; Hess (n 9 413ff; Lein (n 9) 40ff; Masters and McRae (n 23) 496.

92 This view is shared in respect of the German-British Recognition and Enforcement Treaty of 1960 by Staudinger ( $\mathrm{n} 48$ ).

94 See also the overview by Hess (n 9) $413 \mathrm{ff}$.

95 Hess (n 9) 414. See, for example, art VII of the German-British Recognition and Enforcement Treaty as well as Sections 722, 723 of the German Code of Civil Procedure.
} 
became applicable. Referring to Article 66(1) Brussels Ia Regulation, one might be tempted to submit the recognition and enforcement of that judgment to the direct enforcement mechanism of the Regulation. However, the majority rightly rejects this view, ${ }^{96}$ pointing to the decision of the ECJ in Wolf Naturprodukte. ${ }^{97}$ In that case the ECJ held that the Brussels I Regulation applied only if it was in force and applicable both in the original and the enforcement State on the day the judgment was rendered..$^{98}$ It is, therefore, safe to assume that the Court would not apply the direct enforcement systems of the Brussels Ia Regulation to a judgment issued after the day of Brexit.

This finding, of course, raises the question whether the direct enforcement system of the Brussels Ia Regulation might apply after Brexit to a judgment issued before Brexit on the basis of the Brussels Ia Regulation. Pointing to the ECJ's decision in the Wolf Naturprodukte case one might be tempted to answer this question in the affirmative. After all, the ECJ held that the Brussels I Regulation applied if it was in force and applicable in both the original and the enforcement State on the day the judgment was rendered. However, this view would ignore the fact that the Wolf Naturprodukte decision revolved around a case in which the Brussels I Regulation had not yet been in force in the enforcement State on the day the judgment was issued (instead becoming applicable later). In contrast, it did not discuss the question of whether the enforcement regime of the Brussels I Regulation may apply if it is no longer in force and applicable in one of the States involved. Absent a clear provision in the withdrawal agreement it is, therefore, unclear whether the ECJ would actually allow direct enforcement of pre-Brexit English judgments in the remaining Member States - and enforcement of pre-Brexit Member State judgments in the UK — after the day of Brexit. ${ }^{99}$

\section{ALTERNATIVE OPTIONS: A 'SOFT BREXIT' FOR JUDICIAL COOPERATION?}

The preceding analysis suggests that a 'hard Brexit', ie a withdrawal from the UK without any (unilateral, bilateral or multilateral) arrangement for judicial cooperation, would make the settlement of international disputes markedly more complicated and certainly less predictable. ${ }^{100}$ Since issues of choice of

96 See, for example, Dickinson (n 27) 208.

97 ECJ (21 June 2012) C-514/10 - Wolf Naturprodukte GmbH v SEWAR spol. s.r.o., ECLI: EU:C:2012:367.

${ }^{98}$ ECJ (n 97) para 34.

99 Note, however, that both the UK and the EU have recently suggested that the relevant provisions of European Union law should continue to govern all judicial decisions given before the withdrawal date. See HM Government, Providing a Cross-Border Civil Judicial Cooperation Framework. A Future Partnership Paper (n 6) 11 para 7 and the EU Position Paper on Judicial Cooperation in Civil and Commercial Matters (n 8) 2.

${ }^{100}$ See more generally on the problems associated with 'national' private international law and the advantages of unification G Rühl, Statut und Effizienz. Ökonomische Grundlagen des Internationalen Privatrechts (Mohr Siebeck 2011) 39ff, 77ff; G Rühl, 'The Problem of International Transactions: Conflict of Laws Revisited' (2010) 6 JPrivIntL 59, 79ff, $90 \mathrm{ff}$. 
law, jurisdiction and recognition and enforcement would no longer be subject to the same provisions in the UK and the remaining Member States, parties would have a hard time to determining which law would apply, which court would be competent to hear a case and whether a judgment would be enforced abroad. ${ }^{101}$ The worst thing, however, is that commercial parties would no longer be able to trust that choice-of-law and choice-of-forum clauses would do their job and create legal certainty. ${ }^{102}$

Against this background, there is broad consensus both in the UK and in the EU, that the consequences of a 'hard Brexit' should, if at all possible, be avoided. ${ }^{103}$ After all, parties from the UK and the remaining EU Member States will remain important trading partners even after Brexit. And even after Brexit people from the EU will (want to) travel, work and live in the UK just like people from the UK will (want to) travel, work and live in the EU. A predictable, ideally uniform legal framework for judicial cooperation will, therefore, be of the essence for the daily lives of a large number of people. ${ }^{104}$ The remainder of this article will discuss essentially four options for a 'soft Brexit' in the field of judicial cooperation. In so doing it will take into account and critically examine the recently published UK Position Paper on judicial cooperation in civil and commercial matters ${ }^{105}$ as well as the UK Position Paper on enforcement and dispute resolution. ${ }^{106}$

\section{A. Agreement on Continued Application of EU Framework}

The first — and probably best — option for a 'soft Brexit' would certainly be to pretend that Brexit did not happen and to aim for an agreement between the UK and the EU that the Rome I, the Rome II and the Brussels Ia Regulation will continue to apply even after Brexit. ${ }^{107}$ This might look counterintuitive at first sight. After all, it was - and still is - the very purpose of Brexit to get rid

101 Lehmann and Zetzsche (2017) (n 33) 71; Rühl (n 22) 81. See also The General Council of the Bar (n 9) 33ff; and the Report of the European Union Committee of the House of Lords (n 9) 17 para 39, $19 \mathrm{ff}$ para $44 \mathrm{ff}, 20 \mathrm{ff}$ para $52 \mathrm{ff}$.

102 Rühl (n 22) 76ff. See also The General Council of the Bar (n 9) 33.

103 In a similar vein Aikens and Dinsmore (n 21) 913 and 920; Lein (n 9) 35ff and 46; Masters and McRae (n 23) 498. See also The General Council of the Bar (n 9) 29ff, notably 31 as well as the Report of the European Union Committee of the House of Lords (n 9) 33 para 100ff, 34ff para $106 \mathrm{ff}, 41$ para 147,42 para $4 \mathrm{ff}$ and 45 para 34.

${ }^{104}$ HM Government, Providing a Cross-Border Civil Judicial Cooperation Framework. A Future Partnership Paper (n 6) 2 para 1 and 3, 4 para 9, 5 paras 12, 13, 14 and 15, 6 paras 18 and 19, 9 para 24 .

105 ibid (n 6).

106 HM Government, Enforcement and Dispute Resolution. A Future Partnership Paper (n 6).

107 Likewise Aikens and Dinsmore (n 21) 914 (as regards the Brussels Ia Regulation); Lehmann and Zetzsche (2017) (n 33) 71; Lein (n 9) 41 ('ideal solution'); S Masters and B McRae, 'What Next for the Brussels I Regulation (Recast)?' The Lawyer (20 March 2017) 15; Ungerer (n 9) 307. See also the Report of the Justice Committee of the House of Commons (n 33) 16 para 32 as well as the Report of the European Union Committee of the House of Lords (n 9) 11, para 23 and 42 para 1: 'We urge the Government to keep as close to these rules as possible when negotiating their post-Brexit application.' 
of European rules and to take back 'control of our own laws'. ${ }^{108}$ However, the Rome I, the Rome II and the Brussels I Regulation, including the latter's recent recast, were well received in the UK and considered to be a change for the better. ${ }^{109}$ In addition, the draft Withdrawal Bill proves that the UK government has the intention to keep at least some European rules postBrexit as national law post-Brexit. ${ }^{110}$ And since judicial cooperation was not on the agenda of the Brexiteers, ${ }^{111}$ preserving the status quo in private international law would probably not do much political harm. Technically, the agreement could either be part of the withdrawal agreement to be negotiated between the EU and the UK in accordance with Article 50(3) TEU or it could be integrated into an independent treaty along the lines of the Agreement between the EU and Denmark on the application of the Brussels I Regulation ${ }^{112}{ }^{113}$

Of course, obvious and straightforward as the first option might seem at first blush, it comes with a number of problems on closer inspection. To begin with, it does not follow clearly from the UK Position Paper on judicial cooperation whether continued and unconditional application of EU instruments is what the UK government has in mind. To be sure, it emphasizes that common, reciprocal rules which reflect the current EU framework are of the essence. ${ }^{114}$ However, it also makes clear that the UK strives for a new framework for choice of law, jurisdiction and recognition and enforcement of foreign judgments. ${ }^{115}$ But even if the UK were inclined to agree to the continued application of the existing EU instruments, it is not quite clear whether the EU would also do so. ${ }^{116}$ Indeed, the EU might be tempted to withhold its consent for various

108 HM Government, Enforcement and Dispute Resolution. A Future Partnership Paper (n 6) 2 para 2.

109 See, for example, the Report of the European Union Committee of the House of Lords (n 9) $13 \mathrm{ff}$ para $26 \mathrm{ff}$.

${ }_{110}$ See arts 2 and 3 European Union (Withdrawal) Bill, HC Bill 5 2017-19 which will convert large parts of existing secondary European law into domestic law.

111 A Dutta, 'Orbitrechtsakte - eine Idee für das IPR?' (2017) Zeitschrift für Europäisches Privatrecht 533, 534. See, however, R Michaels, 'Does Brexit Spell the Death of Transnational Law?' (2016) 17 German Law Journal (Brexit Special Supplement) 51 who argues that the Brexit Referendum must be understood as a rejection of transnational law including private international law broadly understood.

112 Agreement between the European Community and the Kingdom of Denmark on jurisdiction and the recognition and enforcement of judgments in civil and commercial matters, [2005] OJ L $299 / 62$.

113 Aikens and Dinsmore (n 21) 914; Lehmann and Zetzsche (2016) (n 33) 1025; Lehmann and Zetzsche (2017) (n 33) 71; Lein (n 9) 41; Masters and McRae (n 23) 484ff('ready-made precedent'); Masters and McRae (n 107) 15. See also the recommendation of The General Council of the Bar (n 9) 29 as well as the Report of the Justice Committee of the House of Commons (n 34) 15 para 28,16 para 32,24 para 4 .

114 HM Government, Providing a Cross-Border Civil Judicial Cooperation Framework. A Future Partnership Paper (n 6) 2 para 1, 5 paras 5 and 6 para 19, 9 para 25.

115 ibid 2 paras 2, 3 and 4, 3 para 8,4 para 10, 5 para 11,6 paras 18 and 19,9 para 25.

116 Dickinson (n 5) 563ff. Note that the EU has not yet set out its vision for the future of judicial cooperation, instead having limited its Position Paper on Judicial Cooperation in Civil and Commercial Matters (n 8) to transitional provisions. 
reasons. It might, for example, want to set an example vis-à-vis other Member States that toy with the idea of leaving the EU. ${ }^{117}$ Or it might want to avoid the impression that the UK may 'cherry pick the elements of EU membership that it considers favourable to it'. ${ }^{118}$. And last but not least, it might also be that EU will not be willing to extend the current legal framework to 'a context not presided by the philosophy of integration'. ${ }^{119}$ In other words, the 'blind reciprocal trust' ${ }^{120}$ that comes in particular with application of the Brussels Ia Regulation might be considered as being available only to States that take part in and commit to the 'greater common good'121 of European integration. The EU's consent might, therefore, depend on the UK making a credible commitment to some core European values. And, of course, it is unclear whether the UK will be ready to do so. Media reports that Theresa May is considering withdrawal from the European Convention on Human Rights (ECHR) ${ }^{122}$ after Brexit ${ }^{123}$ rather fuel the concern that the UK will continue to move away from Europe once it has officially left the EU. ${ }^{124}$

Another problem that would come with the continued application of the Rome I, the Rome II and the Brussels Ia Regulations relates to their interpretation and enforcement. The EU's consent to continue applying these EU instruments would certainly depend on the UK accepting the jurisprudence of the ECJ in one form or the other. However, it was - and still is - one of the central aims of Brexit and the UK government to 'bring an end to the direct jurisdiction of the CJEU'. ${ }^{125}$ To bridge these diverging-and seemingly irreconcilable-positions some authors have suggested seeking inspiration from the Agreement between the EU and Denmark on the

117 Croisant (n 27) 28; Masters and McRae (n 23) 486. See also Lein (n 9) 41.

118 Dickinson (n 5) 563ff.

119 M Requejo, 'Brexit and PIL, Over and Over', available at <http://conflictoflaws.net/2017/ brexit-and-pil-over-and-over/>. In a similar vein Dickinson (n 5) 555ff, 556ff.

120 Requejo (n 119). 121 ibid.

122 The Convention for the Protection of Human Rights and Fundamental Freedoms of 4 November 1950, 213 UNTS 221.

123 See, for example, The Independent, 'Theresa May "will campaign to leave the European Convention on Human Rights in 2020 election", , available at <http:/www.independent.co.uk/ news/uk/politics/theresa-may-campaign-leave-european-convention-on-human-rights-2020general-election-brexit-a7499951.html> The Telegraph, 'Theresa May to fight 2020 election on plans to take Britain out of European Convention on Human Rights after Brexit is completed', available at <http://www.telegraph.co.uk/news/2016/12/28/theresa-may-fight-2020-electionplans-take-britain-european/>.

124 More recently, however, the UK government has indicated that it does not have any plans to withdraw from the ECHR. See Department for Exiting the European Union, Legislating for the United Kingdom's Withdrawal from the European Union. White Paper (n 7) 18, para 2.22.

${ }^{125}$ HM Government, Enforcement and Dispute Resolution. A Future Partnership Paper (n 6) 2 para 1. See also Theresa May's speech to the Conservative Party Conference, 'Britain after Brexit: A Vision of a Global Britain' (2 October 2016) available at $<$ https://www.politicshome.com/news/uk/ political-parties/conservative-party/news/79517/read-full-theresa-mays-conservative $>$ : 'Let me be clear. ... we are not leaving only to return to the jurisdiction of the European Court of Justice.'. 
application of the Brussels I Regulation. ${ }^{126}$ Article 6(2) of the Agreement requires Denmark to give 'due account' to ECJ decisions when applying the Brussels I Regulation and, thus, goes a long way to ensuring uniform interpretation. Nonetheless, the EU-Denmark Agreement does not appear to be a good match for the post-Brexit EU-UK relationship. ${ }^{127}$ To begin with, Article 6(1) of the Agreement requires Denmark to refer questions of interpretation as regards the Brussels I Regulation to the ECJ. It is, however, unlikely that the UK will accept being required to turn to the ECJ for interpretative advice (let alone being required to follow it). ${ }^{128}$ By the same token, it is unlikely that the EU will be willing to grant the UK direct access to the ECJ. After all, the UK will—unlike Denmark-no longer be a Member State following Brexit. Ultimately, Article 7(1) allows the Commission to bring proceedings against Denmark if it does not comply with the Agreement. It goes without saying that it is hard to conceive that the UK will submit to any form of supervision by the European Commission after Brexit.

As an alternative model, some authors, ${ }^{129}$ as well as the UK government in its recent Position Paper on enforcement and dispute resolution, ${ }^{130}$ suggest looking to the Lugano Convention of 2007. It regulates the relationship between the EU Member States and third States, namely Switzerland, Norway and Iceland, and thus seems to be better equipped to regulate the relationship between the EU and the UK post Brexit. As regards the jurisdiction of the ECJ, Article 1(1) of Protocol No 2 to the Convention ${ }^{131}$ requires the courts of all contracting States, including the courts of non-Member States, to 'pay due account' to the principles laid down by any court of a contracting State as well as the ECJ concerning the provisions in questions as well as similar provisions of the Lugano Convention of 1988, the Brussels Convention of 1968 and the Brussels I Regulation. However, in contrast to the EU-Denmark Agreement, Protocol No 2 to the Lugano Convention does not require (or allow) the courts of contracting States which are not EU Member States to directly approach the ECJ. Article 2 of the Protocol No 2, however, allows these States to submit statements of cases or written observations and hence guarantees that their voice will be heard. Protocol No 2, therefore, seems to establish a compromise that might turn out to be acceptable for both the EU

\footnotetext{
126 Aikens and Dinsmore (n 21) 915; Masters and McRae (n 23) 486ff; Masters and McRae (n 107) 15. See also Lein (n 9) 41.

127 Likewise the Report of the Justice Committee of the House of Commons (n 34) 115 para 28.

128 Aikens and Dinsmore (n 21) 904; Lein (n 9) 41.

129 See, for example, Aikens and Dinsmore (n 21) 915, 917, 920; Dickinson (n 5) 558ff.

130 HM Government, Enforcement and Dispute Resolution. A Future Partnership Paper (n 6) 9 para 50.

131 Protocol No 2 on the uniform interpretation of the Convention and on the Standing Committee, [2007] OJ L 339/27. See for an overview of the interpretation mechanism of the Lugano Convention of 2007 S Giroud, 'Lugano Convention' in J Basedow, G Rühl, F Ferrari and P de Miguel Asensio (eds), Encyclopedia of Private International Law (Edward Elgar 2017).
} 
and the UK after Brexit. ${ }^{132}$ To be sure, nowhere in any of the Position Papers does the UK government say so explicitly. But the UK government approvingly cites the model of the Lugano Convention when discussing alternatives to direct jurisdiction of the ECJ as regards rules in international treaties that replicate provisions of EU law, ${ }^{133}$ and it has, therefore, indicated that it might be willing to accept jurisprudence of the ECJ along the lines of Protocol No 2. ${ }^{134}$

However, even if the UK and the EU agree on the Lugano model—or if they manage to design a 'new model' to account for the specifics of the post-Brexit situation-yet another problem would most likely arise: the UK would probably want to have a say during any reform process before being required to apply any amendments or changes to the Rome I, the Rome II or the Brussels Ia Regulation. ${ }^{135}$ The EU, in contrast, would not be very inclined to grant the UK a seat at the negotiation table if it is no longer a Member State. A compromise might be to allow UK to join the negotiations as an observer without a voting right. This would at least make sure that the UK position would be heard. As to everything else the EU would probably be willing to offer the UK the same 'deal' as Denmark: according to Article 3(1) and (2) of the EU-Denmark Agreement, Denmark is only bound by amendments to the Brussels I Regulation if it chooses to be so bound and if it notifies the European Commission accordingly. If, however, Denmark decides not to accept the amendments or fails to notify the European Commission or fails to implement the amendments in accordance with Article 3(3) to (5), the entire Agreement will be deemed terminated by virtue of Article 3(7). Whether the UK would be happy with this take-it-or-leave-it approach is, of course, unclear. ${ }^{136}$ However, it is likewise unclear whether the EU would be willing to grant the UK more favourable terms, for example, by allowing application of the unamended versions of the Regulations in cases that bear a relationship to the UK. ${ }^{137}$

\section{B. Negotiation of a New Treaty with the EU}

The second option for a 'soft Brexit' is as straightforward as the first. It consists of negotiating a new international treaty with the EU on issues of choice of law

\footnotetext{
132 Aikens and Dinsmore (n 21) 915; Dickinson (n 5) 559. See also the Report of the European Union Committee of the House of Lords (n 9) 39 para 127, 44 para 23 as well as the Report of the Justice Committee of the House of Commons (n 34) 3, 18 para 35, 24 para 5: ' $\ldots$ a role for the Court of Justice of the European Union in respect of these essentially procedural regulations is a price worth paying to maintain effective cross-border tools of justice'.

133 UK government in its recent Position Paper on enforcement and dispute resolution (n 6) 9 para 50 .

${ }^{134}$ This view is shared by S Peers, Cross-Border Civil Litigation after Brexit: Analysis of the UK Government's Proposals, available at <http://eulawanalysis.blogspot.co.uk/2017/08/cross-bordercivil-litigation-after.html>.

135 Aikens and Dinsmore (n 21) $914 \mathrm{ff}$.

136 See also Masters and McRae (n 23) 486.

137 The obvious disadvantage of any such approach would be that courts in the remaining Member States would have to apply a different set of rules depending on whether the case bears a relationship to the UK or some other State.
} 
and jurisdiction and, of course, recognition and enforcement. ${ }^{138}$ This option probably comes closest to what the UK government has in mind because it clearly reflects its wish for a new civil judicial cooperation framework. ${ }^{139}$ It would allow the UK and the EU to build on the current, reciprocal EU framework - and to improve it where necessary and appropriate. ${ }^{140}$ The UK might, therefore, try to renegotiate the current European position, shaped by various ECJ judgments, as regards the doctrine of forum non conveniens and as regards the use of anti-suit injunctions. The EU on the other hand might appreciate the occasion to review the above-mentioned Regulations and to examine which provisions may be extended to apply to the UK as a nonMember State.

Of course, also this second option comes with problems. To begin with, the negotiation of a new agreement for private international law would be timeconsuming. Considering how many years it took to negotiate the existing EU instruments and considering that judicial cooperation will not be the top priority during the upcoming negotiations, it is unlikely that any such treaty could be signed and enter into force on the day of Brexit. The second option, therefore, would require an interim period during which the current EU instruments would continue to apply-and during which the ECJ would continue to have jurisdiction over these instruments even in the UK. ${ }^{141}$ Whether this would be acceptable for the UK is, of course, unclear. However, the UK Position Paper on judicial cooperation stresses the need for an interim period to ensure a 'smooth and orderly move' 142 from the current to the future framework. This, in turn, seems to suggest that the UK government might be willing to agree to a temporary extension of the existing EU instruments. And even though it is not expressly spelled out in the Position Paper, it also seems to imply that the UK government might be willing to accept a temporary extension of the ECJ's jurisdiction. ${ }^{143}$

Another problem with the second option relates, of course, to enforcement and dispute resolution. A new treaty covering aspects of choice of law and jurisdiction and recognition and enforcement would need to establish a mechanism for resolving disputes. In this context the same issues would arise as if the UK and the EU agreed on continued application of the Rome I, Rome II and the Brussels Ia Regulations. ${ }^{144}$ However, as set out above, Protocol No 2 to

\footnotetext{
138 Lehmann and D'Souza (n 27) 101 call this the 'ideal solution'. See for a detailed discussion of futher merits and demerits of this option Pilich (n 22) $14 \mathrm{ff}$.

139 HM Government, Providing a Cross-Border Civil Judicial Cooperation Framework. A Future Partnership Paper (n 6) 2 paras 1, 2, 3 and 4, 3 para 8, 4 para 10, 5 paras 5, 6 and 11, 6 paras 18 and 19,9 para 25.

141 See for a more detailed discussion Dickinson (n 5) $564 \mathrm{ff}$.

142 HM Government, Providing a Cross-Border Civil Judicial Cooperation Framework. A Future Partnership Paper (n 6) 9 para 23.

143 Peers (n 134). For a more sceptical view see Dickinson (n 5) 564.

144 See Section IV.A.
} 
the Lugano Convention might turn out to be an acceptable compromise for both the UK and the EU. ${ }^{145}$

Against this background, the most serious problem with the second option would be its impact on judicial cooperation at large. To be sure, adoption of a new treaty for private international law would put the relationship between the UK and the EU-in the interests of businesses, families and consumers - on a new base and provide legal certainty. However, it would also, at least from the perspective of the EU, lead to further fragmentation and additional complexity in the field. This is because it would require parties and courts in the remaining Member States to apply different sets of rules to the same private international law questions depending on whether the case has a connection to another Member State, to the UK or to some other third State.

\section{Unilateral Application of EU Instruments}

The third option becomes attractive if the first two options fail because the UK and the EU do not manage to agree on the continued application of the current legal framework and if they do not manage to agree on a new treaty. In this case the UK could simply decide to apply the Rome I, Rome II and the Brussels Ia Regulations unilaterally and, thus, extend the Withdrawal Bill to judicial cooperation in civil and commercial matters. The problem with this option, however, is that it does not work particularly well for jurisdiction. ${ }^{146}$ And it does not work at all for recognition and enforcement of judgements: ${ }^{147}$ the Brussels Ia Regulation rests on the principle of reciprocity. ${ }^{148}$ Therefore, it does not make sense to recognize choice-of-forum clauses in favour of Member States courts on the basis of the Brussels Ia Regulation if Member States courts will recognize choice-of-forum clauses in favour of UK courts only according to their-at times rather restrictive - national laws. The same obviously holds true for the recognition and enforcement of judgments.

Unilateral application, however, works reasonably well as regards choice of law because neither the Rome I nor the Rome II Regulation requires reciprocity. ${ }^{149}$ The UK in its recent Position Paper on judicial cooperation,

145 ibid

146 Masters and McRae (n 107) 15; Ungerer (n 9) 306ff. See also the Report of the European Union Committee of the House of Lords (n 9) $21 \mathrm{ff}$ para 56ff, 42 para 8 as well as the Report of the Justice Committee of the House of Commons (n 34) 115 para 28.

147 Masters and McRae (n 107) 15; Ungerer (n 9) 306ff. See also the Report of the European Union Committee of the House of Lords (n 9) $21 \mathrm{ff}$ para 56ff, 42 para 8 as well as the Report of the Justice Committee of the House of Commons (n 34) 15 para 28.

148 See on this point generally, without reference to the Brussels Ia Regulation, Department for Exiting the European Union, Legislating for the United Kingdom's Withdrawal from the European Union. White Paper (n 7) 19 para 3.3.

149 Aikens and Dinsmore (n 21) 917 ('best solution'); Croisant (n 27) 31; Dickinson (n 27) 210; Lehmann and D'Souza (n 27) 101 ('the most promising option'); Lehmann and Zetzsche (2017) (n 33) 65; Lein (n 9) 42 ('highly recommended'). See also the recommendations of The General Council of the Bar (n 9) 29, of the European Union Committee of the House of Lords (n 9) 38ff 
therefore, confines itself to saying that it will incorporate the Rome I and II Regulations into domestic law while not mentioning the Brussels Ia Regulations and other EU instruments in the field of judicial cooperation. ${ }^{150}$ Nonetheless, two problems remain. The first relates to the question of whether the English legislature actually can decide unilaterally to apply the Rome I and II Regulations. This is doubtful as regards the Rome I Regulation if one adopts the view taken by many (English) authors that the Rome Convention will revive following Brexit. ${ }^{151}$ This is because the UK will then be bound to apply the Rome Convention by way of public international law and cannot simply choose to replace it by a (national) Act of Parliament calling for application of the Rome I Regulation. If one does not follow the argument advanced in this article that the Rome Convention will not revive following Brexit — and it will probably be for the ECJ to make that call ${ }^{152}$ the UK will first have to denounce the Convention in accordance with its Article 30(3).

The second and certainly more serious problem that remains relates to interpretation. Unilateral application of the Rome I and Rome II Regulations can ensure long-term uniform application — and hence legal certainty — only if the UK also follows or at least 'pays due account' to ECJ decisions ${ }^{153}$ along the lines of, for example, the Lugano Convention of 2007. ${ }^{154}$ However, following Brexit, UK courts will probably be under only a very limited obligation to do so. According to the draft Withdrawal Bill, only lower UK Courts will be required to decide any question as to the validity, meaning or effect of any retained EU law in accordance with any EU case law and any general principles of EU law in force before the day of Brexit. ${ }^{155}$ In contrast, neither the Supreme Court nor High Court will be bound to follow historic ECJ case law. ${ }^{156}$ In addition, no UK court will be bound to follow ECJ case law rendered on or after the day of Brexit. ${ }^{157}$ As a consequence, it is unclear, whether UK courts will systematically apply the Rome I and II Regulations as interpreted by the ECJ

para $125 \mathrm{ff}, 44$ para 22 and of the Justice Committee of the House of Commons (n 34) 115 para 28, 16 para 32,24 para 4.

${ }^{150}$ HM Government, Providing a Cross-Border Civil Judicial Cooperation Framework. A Future Partnership Paper (n 6) 6 para $19 . \quad{ }_{151}^{151}$ See references (n 33).

152 According to the First Protocol on the Interpretation of the 1980 Rome Convention (consolidated version), [1998] OJ C 27/47, the power to interpret the Rome Convention is vested with the ECJ. It should, thus, be for the ECJ to decide whether or not the Rome Convention will remain in force after Brexit or not.

${ }^{153}$ Lehmann and Zetzsche (2016) (n 33) 1009ff; Lehmann and Zetzsche (2017) (n 33) 65.

154 Aikens and Dinsmore (n 21) 917. See also Lehmann and D'Souza (n 27) 101 (finding that ' $[\mathrm{t}$ ] here is reason to hope that $\mathrm{UK}$ and EU member state courts find mutual inspiration in their decisions and a harmonious interpretation') and Lehmann and Zetzsche (2016) (n 33) 1010 (arguing that the UK could achieve legal certainty and harmony 'through deeming ECJ case law as precedents for purposes of the construction of its private international law').

${ }_{155}$ Art 6(3)(a) European Union (Withdrawal) Bill of July 2017.

156 Art 6(4) European Union (Withdrawal) Bill of July 2017.

157 Art 6(1)(a) European Union (Withdrawal) Bill of July 2017. 
and, hence as applied in the remaining EU Member States. ${ }^{158}$ Unilateral application of the Rome I and the Rome II Regulations is thus likely to create only the illusion of uniformity in the long run.

\section{Negotiation and Adoption of International Treaties}

This leads to the fourth option: the UK could replace the current European regime with a more global framework by negotiating new treaties with nonMember State countries in the framework of the Hague Conference on Private International Law and the United Nations Commission on International Trade Law (UNCITRAL). This is in line with UK's commitment to 'increasing international civil judicial cooperation with third parties' ${ }^{159}$ as detailed in the recently published UK Position Paper on choice of law, jurisdiction and recognition and enforcement. It includes the negotiating of new judicial cooperation treaties, but it also covers the signing of Conventions to which the UK is already a party by virtue of its membership in the EU, ${ }^{160}$ such as the Lugano Convention of 2007 and the Hague Choice of Court Convention of 2005. ${ }^{161}$ Both Conventions deal with aspects of jurisdiction as well as recognition and enforcement and are currently in force and applicable in the UK pursuant to Article 216(2) TFEU. The binding force of both Conventions, however, will fall away with the UK's withdrawal from the EU. ${ }^{162}$

\section{Lugano Convention 2007}

The Lugano Convention of 2007 is currently applicable in the EU Member States on the one hand, and in three non-Member States on the other, namely Switzerland, Norway and Iceland. ${ }^{163}$ It regulates jurisdiction as well as recognition and enforcement of foreign judgments in basically the same way as the Brussels I Regulation did before the recast. Signing the Lugano Convention would preserve, therefore, many advantages associated with the old Brussels regime. ${ }^{164}$ However, the process of signing might come with problems. ${ }^{165}$ According to Article 70(1) lit. (a) of the Lugano Convention

\footnotetext{
158 Report of the Justice Committee of the House of Commons (n 34) 17 para 33.

159 HM Government, Providing a Cross-Border Civil Judicial Cooperation Framework. A Future Partnership Paper (n 6) 6 para 21. 160 ibid 6 para 22.

${ }_{161}$ Dickinson (n 5) 209ff; Lein (n 9) 39 and 40; Masters and McRae (n 23) 487ff and 494ff; Masters and McRae (n 107) 15; Ungerer (n 9) 302 and 303. See also the recommendations of The General Council of the Bar (n 9) 29, of the European Union Committee of the House of Lords (n 9) 36ff para 117ff, 44 para 22 and of the Justice Committee of the House of Commons (n 34) 15 para 28,16 para 32,24 para 4 .

162 See for a more detailed discussion Rühl (n 22) $77 \mathrm{ff}$ and Section III.C.

163 See for an overview of the Convention Giroud (n 131).

164 Masters and McRae (n 23) 488ff.

165 Croisant (n 27) 28; Lein (n 9) 39; Masters and McRae (n 23) 488; Rühl (n 22) 78; Ungerer (n 9) 303.
} 
only Member States of the European Economic Area (EEA) may become contracting States without further requirements. The UK, however, is currently not an EEA State and, thus far it does not look as if the UK has any intention of becoming one (again) for the very simple reason that this would require the UK to guarantee the very four fundamental freedoms ${ }^{166}$ that the Brexiteers wanted to move away from. ${ }^{167}$

In order to join the Lugano Convention, the UK would, therefore, have to proceed in accordance with Article 70(1) lit. (c) which, in turn, would require the UK to submit its civil justice system to an extreme vetting procedure and to agree to 'pay due account' to ECJ decisions. ${ }^{168}$ And while the UK has not yet expressly said that it would do so, the UK Position Paper on judicial cooperation suggests that the UK is actually willing to do just that. ${ }^{169}$ The real stumbling block for the UK's accession to the Lugano Convention of 2007 might, therefore, be that all other contracting States, including all EU Member States, would have to consent unanimously to the UK joining the Lugano Convention. And, of course, it is unclear, how inclined the remaining EU Member States are to let the UK in. ${ }^{170}$

In any event, however, accession to the Lugano Convention of 2007 would not be the solution to all problems. ${ }^{171}$ This is because the Lugano Convention has not been aligned with the Brussels Ia Regulation, and there are currently no plans of doing so in the near future. ${ }^{172}$ As a consequence, the substantial

166 Article 1(2) Agreement on the European Economic Area of 17 March 1993, [1994] OJ L 1.

167 See for an overview of the likely problems associated with joining the EEA Lehmann and Zetzsche (2016) (n 33) 1000ff; Lehmann and Zetzsche (2017) (n 33) 62ff.

168 For a brief account of the Lugano Convention's interpretation mechanism see Section IV.A.

169 HM Government, Providing a Cross-Border Civil Judicial Cooperation Framework. A Future Partnership Paper (n 6) 6 para 22: ‘... we will seek to continue to participate in the Lugano Convention ...'. See also HM Government, Enforcement and Dispute Desolution. A Future Partnership Paper (n 6) 9 para 50, where the UK government refers-apparently approvingly - to the Lugano Convention as an example of a convention that requires a third State 'to pay account to the principles laid down by any relevant decision delivered by courts of the other Contracting States concerning provisions of this Convention'.

${ }^{170}$ See on this point Croisant (n 27) 28 (arguing that some EU Member States might want to set an example vis-à-vis other Member States considering departure from the EU or that some EU Member States might want to increase their share of the dispute resolution market); Dickinson (n 5) 559. See also the Report of the European Union Committee of the House of Lords (n 9) 45 para 33. Contra, however, Lehmann and Zetzsche (2016) (n 33) 1025 (arguing that '[i]t is hard to imagine that the EU would deny such consent, given its interest in judicial cooperation with the UK').

${ }_{171}$ Aikens and Dinsmore (n 21) 913ff, 915; Croisant (n 27) 28; Lein (n 9) 39; Masters and McRae (n 23) 489; Masters and McRae (n 107) 15. Ungerer (n 9) 303ff. See also the Report of the European Union Committee of the House of Lords (n 9) 39 para 128 and 45 para 33 as well as the Report of the Justice Committee of the House of Commons (n 34) 115 para 28.

172 See the information provided on the website of the Swiss Federal Office of Justice at $<\mathrm{https}: / /$ www.bj.admin.ch/bj/en/home/wirtschaft/privatrecht/lugue-2007.html >: 'At its second meeting (25 September 2013), the Standing Committee on the LugC discussed the possible modification of the revised Lugano Convention (LugC) to bring it line with the new version of the Brussels I Regulation $(1215 / 2012)$. The Standing Committee made no recommendation on the possible amendment of the Lugano Convention and did not decide on any further steps.'. 
improvements that the recast has brought about, some of which were introduced because the UK lobbied hard for them, ${ }^{173}$ would not extend to the UK. ${ }^{174}$ The UK would, therefore, not benefit from the abolition of exequatur that allows parties to enforce judgments from one Member State in any other Member State according to essentially the same procedure as domestic judgments. By the same token, the UK would not benefit either from the new Article 25 which allows parties to choose the court of a Member State regardless of their domicile or from the new Article 31 which reverses the infamous ECJ Gasser judgment ${ }^{175}$ and requires a Member State court to stay proceedings if it has been seized in violation of an exclusive jurisdiction agreement. Finally, the new Articles 33 and 34, which allow courts in a Member State to stay proceedings in favour of courts in third States if certain requirements are met would likewise not apply in relation to the UK.

\section{Hague Choice of Court Convention 2005}

The situation looks much brighter for the Hague Choice of Court Convention of 2005. ${ }^{176}$ In contrast to the Lugano Convention 2007 the UK could sign that Convention on the very day of Brexit because Article 27(1) and (3) of the Convention allows any State to accede. ${ }^{177}$ And, it would help to avoid at least some of the negative effects of a 'hard Brexit' because the Convention will ensure enforcement of choice-of-forum clauses in the contracting States-including all Member States of the EU with the exception of Denmark - as well as enforcement of all judgments rendered on the basis of any such choice-of-forum clauses. ${ }^{178}$

Nonetheless, becoming a party to the Hague Convention would not solve all problems. To begin with, its substantive scope is limited: ${ }^{179}$ Pursuant to Article 1 it applies only to exclusive choice-of-forum clauses concluded in an international situation in civil and commercial matters that are not excluded by virtue of the-fairly long-list found in Article 2 . In addition, also the geographic scope of the Convention is limited. ${ }^{180}$ In fact, the Convention is not-at least not yet - the global convention it was meant to be. It is in force

\footnotetext{
173 See for a more general account of the UK's contribution to the current EU framework for private international law Pilich (n 22) 7ff. $\quad 174$ Aikens and Dinsmore (n 21) 913.

175 ECJ, 9 December 2003, C-116/02 - Erich Gasser GmbH v. MISAT, ECR 2003 I-14693.

176 See for a detailed discussion of the Convention P Beaumont, 'Hague Choice of Court Agreements Convention 2005: Background, Negotiations, Analysis and Current Status' (2009) 5 JPrivIntL 125; M Fallon and S Francq, 'L'incidence de l'entrée en vigueur de la Convention de La Haye de 2005 sur les accords d'élection de for sur l'article 25 du règlement Bruxelles Ibis' (2016) Journal des tribunaux 169.

177 Lein (n 9) 40; Ungerer (n 9) 304ff. See also Ahmed and Beaumont (n 79) 409ff.

178 Dickinson (n 27) 210; Lehmann and D'Souza (n 27) 103; Masters and McRae (n 23) 494. See also M Ahmed, 'BREXIT and English Jurisdiction Agreements: The Post-Referendum Legal Landscape’ (2016) 27 EBLR 989, 994ff.

179 Croisant (n 27) 29; Masters and McRae (n 23) 495.

180 See also the Report of the Justice Committee of the House of Commons (n 34) 115 para 28.
} 
only in the EU, Mexico and Singapore, ${ }^{181}$ and it thus still has a somewhat limited reach. For the same reason there is as of yet little experience with the workings of the Convention in practice. ${ }^{182}$

\section{CONCLUSIONS}

Judicial cooperation in civil and commercial matters is generally perceived to be of a rather 'specialist and technical nature'. ${ }^{183}$ Therefore, it did not play a major role in the public discussions during the Brexit referendum campaign, nor has it attracted much public or political attention since. ${ }^{184}$ However, for 'UK and EU citizens, families and businesses, who work, live, travel and do business within the EU'185 the legal framework for choice of law, jurisdiction and recognition and enforcement is of paramount importance. ${ }^{186}$ Consequently, without any clear rules as regards judicial cooperation firms and individuals from both the UK and the EU would have to carry the post-Brexit burden of decreased legal certainty and potentially disruptive legal proceedings. ${ }^{187}$

Unfortunately, given the many political constraints, especially as regards the future role of the ECJ, there is no easy and no perfect way out of the 'mess' Brexit will create. However, the best short-term option for both the UK and the EU would be either to agree on the continued application of the existing EU instruments ${ }^{188}$ or to strive for the conclusion of a new agreement that closely replicates these instruments. ${ }^{189}$ If no such agreement can be reached - because, for example, the UK and the EU cannot settle the issues of enforcement and dispute resolution - the UK should apply the Rome I and Rome II Regulations unilaterally ${ }^{190}$ and become a party to the Lugano Convention of 2007 as well as the Hague Convention on Choice of Court Agreements. ${ }^{191}$ However, for the reasons set out above, this would certainly not be more than the second-best option. ${ }^{192}$ In the medium- and long-term both the UK and the EU are probably well advised to apply a more global strategy and to foster the conclusion of international treaties in the framework of the Hague Conference on Private International Law. ${ }^{193}$

\footnotetext{
181 See the status chart available at $<$ https://www.hcch.net/en/instruments/conventions/statustable $/$ ?cid $=98>$.

182 Masters and McRae (n 23) 495.

${ }_{183}$ See also the Report of the European Union Committee of the House of Lords (n 9) 8 para 7.

184 ibid. $\quad{ }_{185}$ Report of the European Union Committee of the House of Lords (n 9) 3.

186 ibid 3, 42 para 2. $\quad 187$ ibid 42 para 4 ff. $\quad 188$ See Section IV.A.

189 See Section IV.B. $\quad 190$ See Section IV.C. $\quad{ }^{191}$ See Section IV.D.

192 This is why Dickinson (n 27) 210 calls this option the 'consolation prize'.

193 See Section IV.D. In this context it is of interest that the Hague Conference has recently revived the idea of a Jurisdiction and Enforcement Convention with potentially global application ('Judgments Project') and has entrusted a Special Commission with the preparation of a Draft Convention. For more information see $<$ https://www.hcch.net/en/projects/legislativeprojects/judgments>.
} 